\title{
Front Matter: Volume 8017
}

, "Front Matter: Volume 8017," Proc. SPIE 8017, Detection and Sensing of Mines, Explosive Objects, and Obscured Targets XVI, 801701 (22 June 2011); doi: $10.1117 / 12.901333$

SPIE Event: SPIE Defense, Security, and Sensing, 2011, Orlando, Florida, United SPIE. States 


\section{PROCEEDINGS OF SPIE}

\section{Defection and Sensing of Mines, Explosive Objects, and Obscured Targets XVI}

Russell S. Harmon

John H. Holloway, Jr.

J. Thomas Broach

Editors

25-29 April 2011

Orlando, Florida, United States

Sponsored and Published by

SPIE 
The papers included in this volume were part of the technical conference cited on the cover and title page. Papers were selected and subject to review by the editors and conference program committee. Some conference presentations may not be available for publication. The papers published in these proceedings reflect the work and thoughts of the authors and are published herein as submitted. The publisher is not responsible for the validity of the information or for any outcomes resulting from reliance thereon.

Please use the following format to cite material from this book:

Author(s), "Title of Paper," in Detection and Sensing of Mines, Explosive Objects, and Obscured Targets XVI, edited by Russell S. Harmon, John H. Holloway, Jr., J. Thomas Broach, Proceedings of SPIE Vol. 8017 (SPIE, Bellingham, WA, 2011) Article CID Number.

ISSN 0277-786X

ISBN 9780819485915

Published by

SPIE

P.O. Box 10, Bellingham, Washington 98227-0010 USA

Telephone +1 3606763290 (Pacific Time) · Fax +1 3606471445

SPIE.org

Copyright (C) 2011, Society of Photo-Optical Instrumentation Engineers

Copying of material in this book for internal or personal use, or for the internal or personal use of specific clients, beyond the fair use provisions granted by the U.S. Copyright Law is authorized by SPIE subject to payment of copying fees. The Transactional Reporting Service base fee for this volume is $\$ 18.00$ per article (or portion thereof), which should be paid directly to the Copyright Clearance Center (CCC), 222 Rosewood Drive, Danvers, MA 01923. Payment may also be made electronically through CCC Online at copyright.com. Other copying for republication, resale, advertising or promotion, or any form of systematic or multiple reproduction of any material in this book is prohibited except with permission in writing from the publisher. The CCC fee code is 0277-786X/11/ \$18.00.

Printed in the United States of America.

Publication of record for individual papers is online in the SPIE Digital Library.

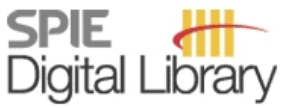

SPIEDigitalLibrary.org

Paper Numbering: Proceedings of SPIE follow an e-First publication model, with papers published first online and then in print and on CD-ROM. Papers are published as they are submitted and meet publication criteria. A unique, consistent, permanent citation identifier (CID) number is assigned to each article at the time of the first publication. Utilization of CIDs allows articles to be fully citable as soon as they are published online, and connects the same identifier to all online, print, and electronic versions of the publication. SPIE uses a six-digit CID article numbering system in which:

- The first four digits correspond to the SPIE volume number.

- The last two digits indicate publication order within the volume using a Base 36 numbering system employing both numerals and letters. These two-number sets start with 00, 01, 02, 03, 04, $05,06,07,08,09,0 A, 0 B \ldots 0 Z$, followed by 10-1Z, 20-2Z, etc.

The CID number appears on each page of the manuscript. The complete citation is used on the first page, and an abbreviated version on subsequent pages. Numbers in the index correspond to the last two digits of the six-digit CID number. 


\section{Contents}

$\begin{array}{cl}x i & \text { Conference Committee } \\ x V & \text { Introduction }\end{array}$

\section{SESSION 1 ELECTROMAGNETIC INDUCTION I}

801702 Open-area concealed-weapon detection system [8017-01]

P. Pati, P. Mather, Univ. of Huddersfield (United Kingdom)

801703 Magnetic sensing techniques for humanitarian ordnance detection and discrimination [8017-02]

J. Keranen, S. Billings, G. Schultz, J. Miller, Sky Research, Inc. (United States)

801704 Incorporating advanced EMI technologies in operational munitions characterization surveys [8017-03]

J. S. Miller, F. Shubiditze, Sky Research, Inc. (United States); L. Pasion, Sky Research, Inc. (Canada); G. Schultz, H. Chung, Sky Research, Inc. (United States)

801705 Rapid position estimation using electromagnetic induction data from the MetalMapper in dynamic mode [8017-04]

T. M. Grzegorczyk, Delpsi, LLC (United States); B. Barrowes, U.S. Army Cold Regions Research and Engineering Lab. (United States); D. George, G\&G Sciences, Inc. (United States); F. Shubitidze, Thayer School of Engineering at Dartmouth (United States) J. P. Fernández, Consultant (United States); K. O'Neill, U.S. Army Cold Regions Research and Engineering Lab. (United States)

801706 Comparison of supervised and unsupervised machine learning techniques for UXO classification using EMI data [8017-05]

A. Bijamov, Thayer School of Engineering at Dartmouth (United States); F. Shubitidze, Thayer School of Engineering at Dartmouth (United States) and Sky Research, Inc. (United States); J. P. Fernandez, Consultant (United States); I. Shamatava, Sky Research, Inc. (United States) and Thayer School of Engineering at Dartmouth (United States); B. E. Barrowes, K. O'Neill Thayer School of Engineering at Dartmouth (United States) and U.S. Army Cold Regions Research and Engineering Lab. (United States)

801707 MPV-II: an enhanced vector man-portable EMI sensor for UXO identification [8017-06] J. P. Fernández, Consultant (United States); B. Barrowes, Thayer School of Engineering at Dartmouth (United States) and U.S. Army Cold Regions Research and Engineering Lab. (United States); A. Bijamov, Thayer School of Engineering at Dartmouth (United States); T. Grzegorczyk, Delpsi, LLC (United States); N. Lhomme, Sky Research, Inc. (Canada); K. O'Neill, Thayer School of Engineering at Dartmouth (United States) and U.S. Army Cold Regions Research and Engineering Lab. (United States); I. Shamatava, F. Shubitidze, Thayer School of Engineering at Dartmouth (United States) and Sky Research, Inc. (United States) 
801708 Inversion of dynamically repositioned multi-axis electromagnetic data for ordnance characterization [8017-07]

J. Keranen, F. Shubitidze, Sky Research, Inc. (United States); L. Besaw, M. J. Casari, Applied Research Associates, Inc. (United States); J. Miller, G. Schultz, Sky Research, Inc. (United States)

\section{SESSION 2 ELECTROMAGNETIC INDUCTION II}

801709 Live-site UXO classification studies using advanced EMI and statistical models [8017-08] I. Shamatava, Sky Research, Inc. (United States) and Thayer School of Engineering at Dartmouth (United States); F. Shubitidze, Thayer School of Engineering at Dartmouth (United States) and Sky Research, Inc. (United States); J. P. Fernandez, Consultant (United States); A. Bijamov, Thayer School of Engineering at Dartmouth (United States); B. E. Barrowes, K. O'Neill, Thayer School of Engineering at Dartmouth (United States) and U.S. Army Cold Regions Research and Engineering Lab. (United States)

8017 OA Advanced UXO discrimination: resolving multiple targets and overlapping EMI signals [8017-09]

F. Shubitidze, Thayer School of Engineering at Dartmouth (United States) and Sky Research, Inc. (United States); B. E. Barrowes, Sky Research, Inc. (United States) and U.S. Army Cold Regions Research and Engineering Lab. (United States); I. Shamatava, Sky Research, Inc. (United States) and Thayer School of Engineering at Dartmouth (United States);

J. P. Fernandez, Consultant (United States); A. Bijamov, Thayer School of Engineering at Dartmouth (United States); K. O'Neill, Sky Research Inc. (United States) and U.S. Army Cold Regions Research and Engineering Lab. (United States)

$8017 \mathrm{OB} \quad$ Frequency domain electromagnetic induction sensor data feature extraction and processing for improved landmine detection [8017-10]

S. L. Tantum, K. D. Morton, Jr., L. M. Collins, P. A. Torrione, Duke Univ. (United States)

8017 OC EMI sensor positioning using a beacon approach [8017-11]

N. Lhomme, Sky Research, Inc. (Canada); B. E. Barrowes, U.S. Army Cold Regions Research and Engineering Lab. (United States); D. C. George, G\&G Sciences Inc. (United States)

8017 OD Hand-held multi-sensor system design dedicated to mine detection [8017-81] M. Sezgin, M. Çayır, M. Doğru, M. Dağ, H. Nazlı, E. Özkan, F. Yaldız, E. Bıçak, H. Öztürk, A. Kaplaner, TUBITAK BILGEM BTE (Turkey)

\section{SESSION 3 A MÉLANGE OF TECHNIQUES}

8017 OE Synthetic aperture acoustic imaging of canonical targets with a 2-15 kHz linear FM chirp [8017-12]

J. F. Vignola, J. A. Judge, C. E. Good, The Catholic Univ. of America (United States); S. S. Bishop, P. M. Gugino, U.S. Army Night Vision and Electronic Sensors Directorate (United States); M. Soumekh, Soumekh Consulting (United States)

8017 OF Detection of unintended electromagnetic emissions from super-regenerative receivers [8017-13] J. Hertenstein, DRS Sustainment Systems, Inc. (United States); S. Jagannathan, Missouri Univ. of Science and Technology (United States) 
8017 OG Ground target stimulation using a moving microwave source [8017-14]

D. Heberlein, B. Balko, I. Kohlberg, J. Biddle, J. Franklin, Institute for Defense Analyses (United States)

8017 OH DS Sentry: an acquisition ASIC for smart, micro-power sensing applications [8017-15] J. Liobe, M. Fiscella, E. Moule, M. Balon, ADVIS, Inc. (United States); M. Bocko, Z. Ignjatovic, Univ. of Rochester (United States)

8017 Ol Threat detection in desert environment with passive millimeter-wave sensor [8017-16] J. P. Wilson, Univ. of Delaware (United States); C. A. Schuetz, R. D. Martin, T. E. Dillon, Phase Sensitive Innovations, Inc. (United States); M. Murakowski, D. W. Prather, Univ. of Delaware (United States)

$80170 \mathrm{~J} \quad$ Laser neutralization of buried munitions [8017-17]

J. D. Habersat, B. W. Schilling, J. Alexander, U.S. Army Night Vision and Electronic Sensors Directorate (United States); R. McElhaney, Cobham Analytic Solutions (United States); T. Lehecka, The Pennsylvania State Univ.-Electro-Optics Ctr. (United States); M. D. Nixon, Boeing-SVS, Inc. (United States)

\section{SESSION 4 SENSING AND DETECTING IN THE MARINE ENVIRONMENT I}

8017 OK Automation for underwater mine recognition: current trends and future strategy [8017-18] J. Stack, Office of Naval Research (United States)

8017 OM Seabed segmentation in synthetic aperture sonar images [8017-20] J. T. Cobb, Naval Surface Warfare Ctr. Panama City Div. (United States); J. Principe, Univ. of Florida (United States)

8017 ON Optimal frame pursuit for pattern classification [8017-21]

J. C. Isaacs, Naval Surface Warfare Ctr. (United States)

801700 Statistical analysis and classification of acoustic color functions [8017-22] J. D. Tucker, Naval Surface Warfare Ctr. (United States); A. Srivastava, Florida State Univ. (United States)

8017 OP Seabed change detection in challenging environments [8017-23]

C. A. Matthews, D. D. Sternlicht, Naval Surface Warfare Ctr. Panama City Div. (United States)

\section{SESSION 5 SENSING AND DETECTING IN THE MARINE ENVIRONMENT II}

8017 OQ Laplace-Beltrami eigenfunctions for 3D shape matching [8017-24]

J. C. Isaacs, Naval Surface Warfare Ctr. (United States)

8017 OR Deformable Bayesian networks for data clustering and fusion [8017-25]

K. Kampa, J. C. Principe, Univ. of Florida (United States); J. T. Cobb, Naval Surface Warfare Ctr. Panama City Div. (United States); A. Rangarajan, Univ. of Florida (United States)

8017 OS Bayesian surprise metric for outlier detection in on-line learning [8017-26]

E. Hasanbelliu, K. Kampa, Univ. of Florida (United States); J. T. Cobb, Naval Surface Warfare Ctr., Panama City Div. (United States); J. C. Príncipe, Univ. of Florida (United States) 
8017 OT Low-noise magnetic sensing for marine munitions characterization [8017-27]

G. Schultz, J. Keranen, S. Billings, R. Fonda, J. Foley, C. Bassani, Sky Research, Inc. (United States)

8017 OU Active source electromagnetic methods for marine munitions [8017-28]

G. Schultz, F. Shubiditze, J. Miller, Sky Research, Inc. (United States); R. Evans, Woods Hole Oceanographic Institute (United States)

8017 OV Investigating Tx coils and magnetic field Rx sensor configurations for underwater geo-location [8017-29]

F. Shubitidze, A. Bijamov, Thayer School of Engineering at Dartmouth (United States);

G. Schultz, J. Miller, Sky Research, Inc. (United States); I. Shamatava, Thayer School of

Engineering at Dartmouth (United States) and Sky Research, Inc. (United States)

\section{SESSION 6 SOILS AND SOIL EFFECTS}

8017 OW Coaxial line measurement and analysis of electromagnetic properties of soils for sensor applications [8017-30]

W. R. Folks, Sentel Corp. (United States); R. E. North, J. R. Kelley, U.S. Army Corps of Engineers (United States); A. L. Cunningham, Sentel Corp. (United States); J. R. McKenna, U.S. Army

Corps of Engineers (United States)

8017 0X Performance of demining sensors and soil properties [8017-31]

K. Takahashi, H. Preetz, J. Igel, Leibniz Institute for Applied Geophysics (Germany)

8017 OY Effects of different soil types on strip-map GPR SAR images [8017-32]

H. Nazli, M. Sezgin, TUBiTAK BILGEM BTE (Turkey)

801710 High-resolution soil moisture mapping in Afghanistan [8017-34]

J. M. H. HendrickX, J. B. J. Harrison, B. Borchers, New Mexico Institute of Mining and

Technology (United States); J. R. Kelley, S. Howington, J. Ballard, Coastal and Hydraulics Lab. (United States)

\section{SESSION 7 DETECTION OF BULK EXPLOSIVES THREATS I}

801711 Principles and status of neutron-based inspection technologies (Invited Paper) [8017-35]

T. Gozani, Rapiscan System Labs., Inc. (United States)

801713 Portable and autonomous $x$-ray equipment for in-situ threat materials identification by effective atomic number high-accuracy measurement [8017-37]

M. Iovea, M. Neagu, G. Mateiasi, Accent Pro 2000 s.r.l. (Romania); O. Duliu, Univ. of Bucharest (Romania)

801714 Defence Research and Development Canada: Suffield research on nuclear methods for detection of buried bulk explosives (Invited Paper) [8017-38]

J. E. McFee, A. A. Faust, Defence Research and Development Canada, Suffield (Canada) 
801715 Nuclear quadrupole resonance detection of explosives: an overview [8017-39]

J. B. Miller, Naval Research Lab. (United States)

801716 Observations on military exploitation of explosives detection technologies [8017-40]

A. A. Faust, Defence Research and Development Canada, Suffield (Canada);

C. J. de Ruiter, TNO Defence, Security and Safety (Netherlands); A. Ehlerding, Swedish Defence Research Agency (Sweden); J. E. McFee, Defence Research and Development Canada, Suffield (Canada); E. Svinsås, A. D. van Rheenen, FFI, Norwegian Defence Research Establishment (Norway)

801717 Explosives (and other threats) detection using pulsed neutron interrogation and optimized detectors [8017-41]

D. A. Strellis, M. Elsalim, T. Gozani, Rapiscan Labs. (United States)

801718 A non-imaging polarized terahertz passive system for detecting and identifying concealed explosives [8017-42]

M. A. Karam, D. Meyer, Northrop Grumman Navigation Systems (United States)

\section{SESSION 9 STANDOFF DETECTION OF EXPLOSIVES}

801719 Detection and identification of explosives hidden under barrier materials: what are the THz-technology challenges? [8017-43]

A. D. van Rheenen, M. W. Haakestad, Norwegian Defence Research Establishment (Norway)

8017 1B Stand-off detection of explosive particles by imaging Raman spectroscopy [8017-45] M. Nordberg, Swedish Defence Research Agency (Sweden) and Royal Institute of Technology (Sweden); M. Åkeson, H. Östmark, T. E. Carlsson, Swedish Defence Research Agency (Sweden)

8017 1C Picosecond laser pulses improves sensitivity in standoff explosive detection [8017-46] M. Åkeson, Portendo AB (Sweden); M. Nordberg, Swedish Defence Research Agency (Sweden) and Royal Institute of Technology (Sweden); A. Ehlerding, Swedish Defence Research Agency (Sweden); L.-E. Nilsson, Portendo AB (Sweden); H. Östmark, Swedish Defence Research Agency (Sweden); P. Strömbeck, Portendo AB (Sweden)

\section{SESSION 10 ADVANCES IN GROUND PENETRATING RADAR SUBSURFACE OBJECT DETECTION}

8017 1D Random GPR antennae height variations and mine detection performance [8017-49] G. M. Milner, AARD, LLC (United States)

$8017 \mathrm{IE}$ Detection of explosive hazards using spectrum features from forward-looking ground penetrating radar imagery [8017-50]

J. Farrell, T. C. Havens, K. C. Ho, J. M. Keller, Univ. of Missouri (United States); T. T. Ton,

D. C. Wong, U.S. Army Night Vision and Electronic Sensors Directorate (United States); M. Soumekh, Univ. of New York at Buffalo (United States) 
8017 IF Narrow-band processing and fusion approach for explosive hazard detection in FLGPR [8017-51]

T. C. Havens, J. M. Keller, K. C. Ho, Univ. of Missouri-Columbia (United States); T. T. Ton,

D. C. Wong, U.S. Army Night Vision and Electronic Sensors Directorate (United States);

M. Soumekh, Univ. at Buffalo (United States)

8017 1G Layer segmentation of GPR images using relaxation labeling for landmine detection [8017-52]

M. A. Laffin, M. A. Mohamed, A. Etebari, NIITEK, Inc. (United States); M. W. Hibbard, CoVar Applied Technologies, Inc. (United States)

\section{SESSION 11 TRACKING ROUGH GROUND IN GROUND-PENETRATING RADAR DATA}

$8017 \mathrm{1H}$ The Viterbi algorithm as an approach for incorporating spatial information into air/ground interface inference in GPR data [8017-53]

P. A. Torrione, K. Morton, Jr., L. M. Collins, Duke Univ. (United States)

801711 DynaMax+ ground-tracking algorithm [8017-54]

B. Smock, P. Gader, J. Wilson, Univ. of Florida (United States)

$80171 \mathrm{~J}$ Support vector data description for detecting the air-ground interface in ground penetrating radar signals [8017-55]

J. Wood, J. Wilson, Univ. of Florida (United States)

$80171 \mathrm{~L} \quad$ Comparison of algorithms for finding the air-ground interface in ground penetrating radar signals [8017-57]

J. Wood, J. Bolton, G. Casella, Univ. of Florida (United States); L. Collins, Duke Univ. (United States); P. Gader, T. Glenn, J. Ho, Univ. of Florida (United States); W. Lee, R. Mueller, NIITEK, Inc. (United States); B. Smock, Univ. of Florida (United States); P. Torrione, Duke Univ. (United States); K. Watford, J. Wilson, Univ. of Florida (United States)

\section{SESSION 12 SIGNAL PROCESSING GROUND-PENETRATING RADAR DATA I}

$80171 \mathrm{M}$ Observations on syntactic landmine detection using impulse ground-penetrating radar [8017-58]

A. O. Nasif, K. J. Hintz, George Mason Univ. (United States)

8017 1N Characterization of binary string statistics for syntactic landmine detection [8017-59]

A. O. Nasif, B. L. Mark, K. J. Hintz, George Mason Univ. (United States)

801710 Ground-penetrating radar signal processing for the detection of buried objects [8017-60] M. Walters, E. Garcia, Cornell Univ. (United States)

$80171 \mathrm{P} \quad$ Adaptive Gaussian mixture models for pre-screening in GPR data [8017-61] P. Torrione, K. Morton, Jr., New Folder Consulting, LLC (United States); L. E. Besaw, Applied Research Associates, Inc. (United States)

$80171 Q$ Physics-based features for identifying contextual factors affecting landmine detection with ground-penetrating radar [8017-62]

C. R. Ratto, K. D. Morton, Jr., L. M. Collins, P. A. Torrione, Duke Univ. (United States) 
8017 1R Multiple instance learning framework for landmine detection using ground-penetrating radar [8017-63]

A. Manandhar, K. D. Morton, L. M. Collins, P. A. Torrione, Duke Univ. (United States)

8017 1S Contextual learning in ground-penetrating radar data using Dirichlet process priors [8017-64]

C. R. Ratto, K. D. Morton, Jr., L. M. Collins, P. A. Torrione, Duke Univ. (United States)

$80171 \mathrm{E} \quad$ Exploiting spectral content for image segmentation in GPR data [8017-65]

P. K. Wang, K. D. Morton, Jr., L. M. Collins, P. A. Torrione, Duke Univ. (United States)

$80171 \mathrm{U}$ Comparative analysis of clutter suppression techniques for landmine detection using ground-penetrating radar [8017-80]

A. B. Yoldemir, R. Gürcan, G. B. Kaplan, M. Sezgin, TÜBITAK BILGEM (Turkey)

$80171 \mathrm{~V}$ Detection of buried mines and explosive objects using dual-band thermal imagery [8017-67]

J. J. Lepley, M. T. Averill, SELEX Galileo (United Kingdom)

$80171 \mathrm{~W}$ Investigation of the potential use of hyperspectral imaging for stand-off detection of person-borne IEDs [8017-69]

C. Cooksey, D. Allen, National Institute of Standards and Technology (United States)

$80171 \mathrm{X}$ Characterizing optical properties of disturbed surface signatures [8017-71]

C. A. Hibbitts, The Johns Hopkins Univ. (United States); J. J. Staszewski, Carnegie Mellon Univ. (United States); G. O'Marr, A. Goldberg, The Johns Hopkins Univ. (United States)

$80171 Y$ Gaussian mixture models for measuring local change down-track in LWIR imagery for explosive hazard detection [8017-72]

C. J. Spain, D. T. Anderson, J. M. Keller, M. Popescu, K. E. Stone, Univ. of Missouri (United States)

\section{SESSION $15 \quad$ SIGNAL PROCESSING AND SENSOR FUSION}

$80171 \mathrm{Z}$ Detection of targets in forward-looking infrared imaging using a multiple instance learning framework [8017-73]

M. Popescu, K. Stone, J. M. Keller, Univ. of Missouri (United States)

801720 Sensor fusion approaches for EMI and GPR-based subsurface threat identification [8017-74] P. Torrione, K. Morton, Jr., New Folder Consulting, LLC (United States); L. E. Besaw, Applied Research Associates, Inc. (United States)

801721 Change detection for detecting potential threats in forward-looking video and downward-looking ground-penetrating radar data [8017-75]

P. Torrione, K. Morton, Jr., C. Ratto, M. Gunter, L. Collins, Duke Univ. (United States) 
801722 Algorithm fusion in forward-looking long-wave infrared imagery for buried explosive hazard detection [8017-76]

D. T. Anderson, J. M. Keller, O. Sjahputera, Univ. of Missouri (United States)

801723 Validating spectral spatial detection based on MMPP formulation [8017-77]

A. Trang, S. Agarwal, T. Broach, T. Smith, U.S. Army Night Vision and Electronic Sensors Directorate (United States)

801724 Using predictive distributions to estimate uncertainty in classifying landmine targets [8017-78]

R. Close, K. Watford, T. Glenn, P. Gader, J. Wilson, Univ. of Florida (United States)

801725 Buried explosive hazard detection using forward-looking long-wave infrared imagery [8017-79]

K. Stone, J. M. Keller, M. Popescu, C. J. Spain, Univ. of Missouri-Columbia (United States)

Author Index 


\title{
Conference Committee
}

\author{
Symposium Chair
}

William Jeffrey, HRL Laboratories, LLC (United States)

Symposium Cochair

Kevin P. Meiners, Office of the Secretary of Defense (United States)

Conference Chairs

Russell S. Harmon, U.S. Army Research Office (United States)

John H. Holloway, Jr., Naval Surface Warfare Center Panama City Division (United States)

J. Thomas Broach, U.S. Army Night Vision and Electronic Sensors Directorate (United States)

Program Committee

Benjamin E. Barrowes, U.S. Army Cold Regions Research and Engineering Lab. (United States)

Leslie M. Collins, Duke University (United States)

Gerald J. Dobeck, Naval Surface Warfare Center Panama City Division (United States)

Paul Gader, University of Florida (United States)

John E. McFee, Defence Research and Development Canada (Canada)

Andrzej W. Miziolek, U.S. Army Research Laboratory (United States) Henric Östmark, Swedish Defence Research Agency (Sweden) James M. Sabatier, The University of Mississippi (United States) Motoyuki Sato, Tohoku University (Japan) Mehmet Sezgin, TÜBITAK Marmara Research Center (Turkey) Waymond R. Scott, Jr., Georgia Institute of Technology (United States) Miranda A. Silvious, U.S. Army Night Vision and Electronic Sensors Directorate (United States)

Richard C. Weaver, U.S. Army Night Vision and Electronic Sensors Directorate (United States)

Session Chairs

1 Electromagnetic Induction I

Jay A. Marble, U.S. Army Night Vision and Electronic Sensors Directorate (United States)

Gregory Schultz, Sky Research Inc. (United States) 
2 Electromagnetic Induction II

Jay A. Marble, U.S. Army Night Vision and Electronic Sensors

Directorate (United States)

Gregory Schultz, Sky Research Inc. (United States)

3 A Mélange of Techniques

Steven S. Bishop, U.S. Army Night Vision and Electronic Sensors

Directorate (United States)

J. Thomas Broach, U.S. Army Night Vision and Electronic Sensors

Directorate (United States)

$4 \quad$ Sensing and Detecting in the Marine Environment I

Gerald J. Dobeck, Naval Surface Warfare Center Panama City Division (United States)

J. Tory Cobb, Naval Surface Warfare Center Panama City Division (United States)

$5 \quad$ Sensing and Detecting in the Marine Environment II

Gerald J. Dobeck, Naval Surface Warfare Center Panama City Division (United States)

J. Tory Cobb, Naval Surface Warfare Center Panama City Division (United States)

6 Soils and Soil Effects

Russell S. Harmon, U.S. Army Research Office (United States)

Jan M. H. Hendrickx, New Mexico Institute of Mining and Technology (United States)

7 Detection of Bulk Explosive Threats I

John E. McFee, Defence Research and Development Canada (Canada)

8 Detection of Bulk Explosive Threats II

John E. McFee, Defence Research and Development Canada (Canada)

$9 \quad$ Standoff Detection of Explosives

John E. McFee, Defence Research and Development Canada (Canada)

10 Advances in Ground Penetrating Radar Subsurface Object Detection Jeremy Bolton, University of Florida (United States)

Alina Zare, University of Missouri-Columbia (United States)

11 Tracking Rough Ground in Ground-Penetrating Radar Data

Jeremy Bolton, University of Florida (United States)

Peter A. Torrione, Duke University (United States) 
12 Signal Processing Ground-Penetrating Radar Data I

Richard C. Weaver, U.S. Army Night Vision and Electronic Sensors

Directorate (United States)

Paul Gader, University of Florida (United States)

13 Signal Processing Ground-Penetrating Radar Data II

Richard L. Weaver, University of Illinois at Urbana-Champaign

(United States)

Paul Gader, University of Florida (United States)

14 Infrared

Chris V. Neale, SELEX Galileo Ltd. (United Kingdom)

James J. Staszewski, Carnegie Mellon University (United States)

15 Signal Processing and Sensor Fusion

Pete Howard, U.S. Army Night Vision and Electronic Sensors Directorate (United States)

Robert H. Luke, U.S. Army Night Vision and Electronic Sensors

Directorate

(United States) 
Downloaded From: https://www.spiedigitallibrary.org/conference-proceedings-of-spie on 26 Apr 2023

Terms of Use: https://www.spiedigitallibrary.org/terms-of-use 


\section{Introduction}

In the terrestrial realm, hastily scattered and buried minefields can be a major impediment to military operations. For this reason the remote detection of minefields is a key to the implementation of new Army war-fighting doctrine based on rapid movement. Detection of mines to address Naval doctrine in the marine environment, whether in the surf zone, near-shore region, or in deep water is also a continuing technical challenge. During the last decade, the use of mines and explosive objects as effective defensive weapons and as an inexpensive terrorist alternative has proliferated worldwide. As a result, the detection of mines, explosive objects, and obscured targets remains an ever important topic: not just because of its military related applications, but also for its humanitarian and environmental impacts. It is relatively easy to lay a minefield or use an explosive device but very dangerous, costly, and time consuming to detect, localize and to clear it. In the humanitarian context, the threat of a minefield is that it remains active and in place for a very long time, generally outlasting any minefield documentation. Improvised devices can cause massive personal trauma and these devices present unique detection challenges.

Unexploded ordnance presents a hazard for military operations during and after conflicts, as well as a tremendous environmental liability on lands where it is present as the legacy of decades of testing and training. It is very important, therefore, to directly address these issues in a broad forum. The detection of mines/minefields, other explosive objects like improvised explosive devices, and unexploded ordnance is a challenging problem because of the variability in target shape and size, material, color, and backgrounds and because they can undergo changes once deployed. In general, mine detection is hampered by problems of low detector signal under common environmental conditions. Detection frequently occurs in the presence of significant amounts of both natural and anthropogenic clutter. In order to increase the effectiveness of mine detection it is essential to develop technically superior sensor modalities, better understand environmental effects on sensors, implement innovative uses of sensors, and enhance sensor fusion and data fusion capabilities.

This issue presents a selection of the presentations at the 2011 SPIE Defense, Security + Sensing Symposium that addressed the areas of sensing and detection of explosive object targets in the marine and terrestrial environment by different sensor modalities, the detection of bulk explosives, environmental effects of sensor performance, and sensor signal processing and data fusion.

Thomas Broach John Holloway Russell Harmon 
Downloaded From: https://www.spiedigitallibrary.org/conference-proceedings-of-spie on 26 Apr 2023

Terms of Use: https://www.spiedigitallibrary.org/terms-of-use 